\title{
Assessment of land suitability for the production of major crops in Ayrancı district of Karaman province located at arid terrestrial ecosystem
}

\author{
Güntülü Kurşun a, Orhan Dengiz b,*
}

a Republic of Turkey, Ministry of Agriculture and Forestry, General Directory of Agricultural Reform, Ankara, Turkey b Ondokuz Mayıs University, Faculty of Agriculture, Department of Soil Science and Plant Nutrition, Samsun, Turkey

\section{Article Info}

Received : 01.04.2019

Accepted : 01.11.2019

\begin{abstract}
Land evaluation based on human, economic and physical resources is an important tool for attaining proper land use planning of various agro-ecological zones especially in arid terrestrial ecosystem condition area to ensure that land is not degraded and that it is used according to its capacity to satisfy human needs for present and future generation. The aim of this research was to assess land suitability for the production of major crops in arid terrestrial ecosystem. The study area was carried out Ayrancı district of Karaman province is about $4760 \mathrm{~km}^{2}$ and located between $577076 \mathrm{~m} \mathrm{-} 596768 \mathrm{~m}$ east and $41541331 \mathrm{~m} \mathrm{-}$ $4174001 \mathrm{~m}$ north coordination. Elevation of the study area locates between $991 \mathrm{~m}$ and 1774 $\mathrm{m}$ from sea level and long term annual average precipitation and temperature are $330.8 \mathrm{~mm}$ and $12{ }^{\circ} \mathrm{C}$. According to Newhall simulation model, it was determined that soil temperature regime is mesic and moisture regime is weak aridic. The land mapping units were primarily described and land characteristics and qualities were determined using 1:5.000 scaled soil maps of the study area. Land use types to be considered were described and their land requirements were determined. The land requirement of the land use types were compared with the land characteristics and land qualities of land mapping units. The results of the matching process combined with those of assessment and produced a classification showed the suitability of each land mapping unit for each relevant land use type. The agricultural suitability maps prepared revealed that only $8.4 \%$ of the study area soils was not suitable for agricultural uses, $57.2 \%$ of the soils was best suitable for agricultural uses. In addition, 70515.8 ha of the total study area was not suitable for horticulture cultivation whereas, 9859.1 ha was not suitable for field crop cultivation due to the unfavorable land and soil conditions. Moreover, about $35.4 \%$ of the total area was found non suitable for vegetable crops in the study area.
\end{abstract}

Keywords: Arid land, land use type, land characteristics and qualities, land suitability classification.

(C) 2020 Federation of Eurasian Soil Science Societies. All rights reserved

\section{Introduction}

Undoubtedly, some researchers indicated that one of the ways to provide food is to increase production in area and to use the land with respect to its potentiality in an appropriate way (Dengiz and Başkan, 2009; Ahmed et al., 2015). FAO (2014) recognizes that the adoption of sustainable land-use and land management practices is important for achieving sustainability in its Strategic Objective as "Producers and natural resource managers adopt practices that increase and improve the provision of goods and services in agricultural sector production systems in a sustainable manner". In this sense, land evaluation analysis is a prerequisite to achieving optimum utilization of the available land resources. Lack of knowledge on best combination of factors that suit production of yields has contributed to the low production (Dengiz and Usul, 2018). The term "Land suitability assessment" refers to assessment of land performance to derive maximum

${ }^{*}$ Corresponding author.

Ondokuz Mayis University, Faculty of Agriculture, Department of Soil Science and Plant Nutrition, 55139 Samsun, Turkey

Tel.: +903623121919

E-mail address: odengiz@omu.edu.tr

e-ISSN: 2147-4249 DOI: $10.18393 /$ ejss. 642200 
benefits with minimum degradation when used for a specific purpose. This assessment involves many biophysical factors that directly or indirectly control the ability of this part of land to host the land use under investigation. Performing land suitability evaluation and generating maps of land suitability for agricultural or non-agricultural uses will facilitate to reach sustainable agriculture (FAO, 1976; Vargahan et al., 2011; Rabia and Terribile, 2013). Dengiz et al. (2003) stated that studies of land evaluation are of great importance in guiding decision on land uses in terms of their potential and conserving natural resources for feature generations. Therefore, suitability is a function of land use requirements and land characteristics (Mustafa et al., 2011). That's why, suitability is a measure of how well the qualities of a land unit match the requirements of a particular form of land use (FAO, 1976).

Many methods generally divided into hierarchic and parametric approaches by take into consideration of limitations have been developed for the assessment of land suitability (Dengiz and Sarığlu, 2013; Karimi et al., 2018). Simple limitation, regarding number and intensity of limitations, Storie, and square root (Khiddir, 1986) methods are the most widely used (Sys et al., 1991; Dengiz, 2002; Rabia and Terribile, 2013). Comparative evaluations of the different land suitability methods have been presented by Hopkins (1977) and Anderson (1987). Although results of different land suitability methods are generally similar, the parametric methods frequently underestimate the potential of investigated lands (Rabia and Terribile 2013). Sarvari and Mahmoodi (2001), Dengiz et al. (2005) and Jafarzadeh et al. (2008), and demonstrated more realistic results for agricultural land suitability using the square root method evaluation.

The majority of both limitation and parametric methods use the FAO (1976) framework for land suitability classification. In this framework, lands are classified into five classes ranging from highly suitable to permanently not suitable considering the existing limitations for a specific use (FAO, 1976). In addition to the aforementioned methods, new spatial technologies such as geographic information systems (GIS) and remote sensing. GIS technology enables users to integrate multiple geospatial and attribute data with high precision and flexibility and hence improves land suitability evaluation (Bagherzadeh and Mansouri, 2011; Mendas and Delali 2012; Dengiz, 2013; Hamerlinck and Lieske, 2015). Furthermore, GIS facilitates spatiotemporal analysis of various crop production practices (Laingen, 2015; Flynn, 2016).

To combat land degradation and desertification, harmonizing the often-conflicting objectives of intensified human needs and socio-economic development, while maintaining and enhancing the ecology life support functions of land resources is an obligation (Girma et al., 2015). Therefore, land suitability evaluation is very important to provide information on the constraints and opportunities for the use of the land and therefore guides decisions on optimal utilizations of the resources (Dengiz et al., 2010). Land evaluation based on human, economic and physical resources is an important tool for attaining proper land use planning of various agro-ecological zones especially in arid terrestrial ecosystem condition area to ensure that land is not degraded and that it is used according to its capacity to satisfy human needs for present and future generation. In this present study, it was amid to assess land suitability for the production of major crops in arid terrestrial ecosystem.

\section{Material and Methods}

This research was carried out in Ayanclk district of Karaman province located in Central Anatolia of Turkey and covers about $4760 \mathrm{~km}^{2}$ (Figure 1). In addition, the study area coordinated at 577076 - 596768 East and 41541331 - 4174001 North (Zone 36, WGS84, UTMm).

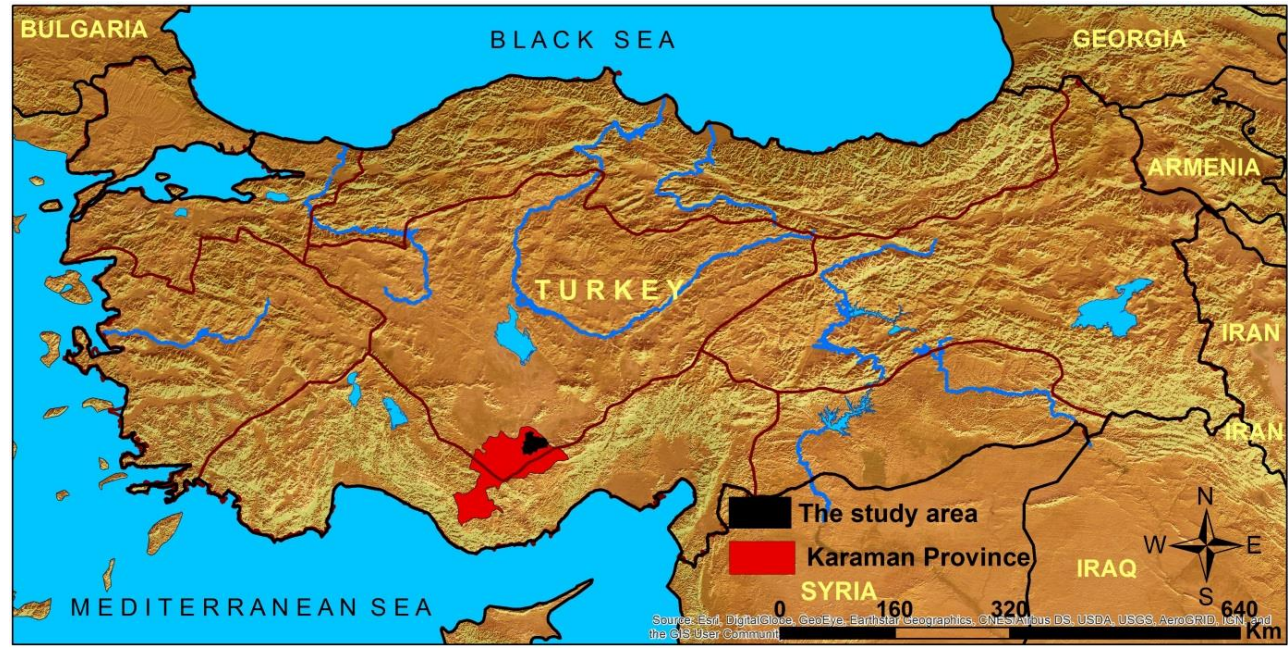

Figure 1. Location map of the study area 
The elevation of the study site from sea level varies between $991 \mathrm{~m}$ and $1774 \mathrm{~m}$. In addition, mountain and hilly topographic features have located at eastern part of the study area while, northwestern and southwestern parts of the study area have flat area. Therefore, steep slope (more than 30\%) distributes mostly eastern direction of the study area (Figure 2).
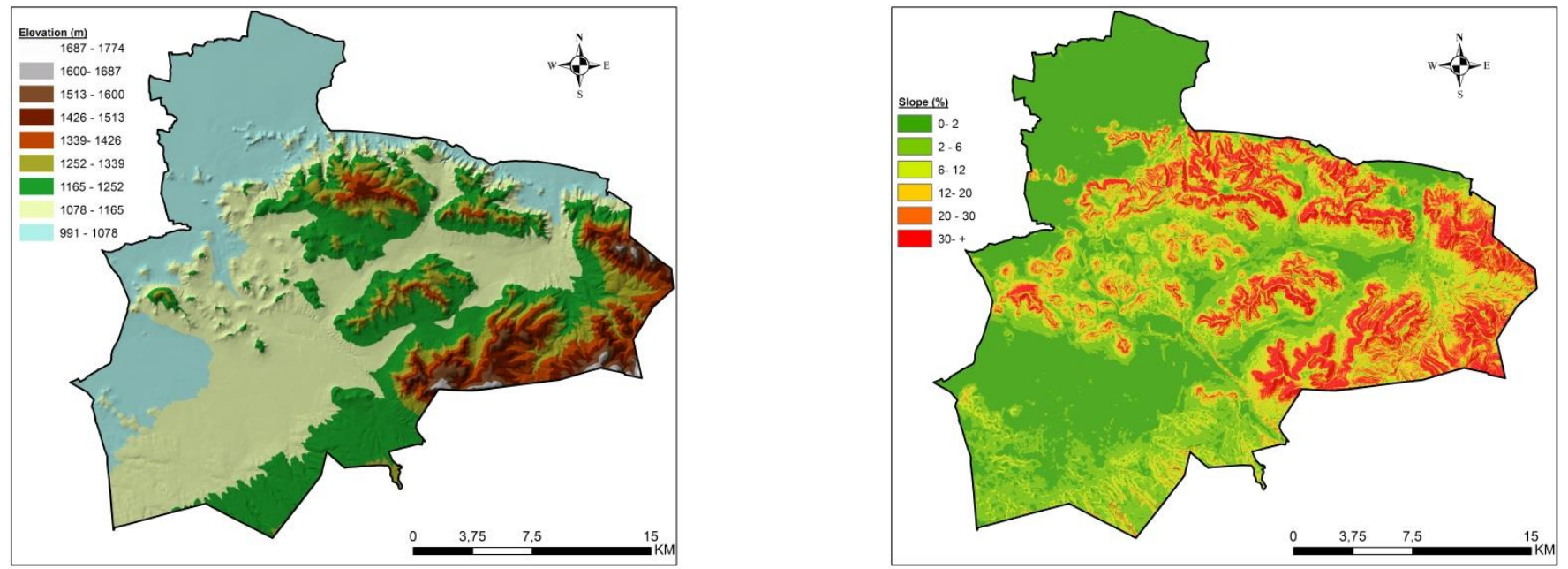

Figure 2. Elevation and slope maps of the study area

In order to reveal the climatic features of the study area, long period data (1960-2015) from the meteorological station of Karaman province has been used. The average annual temperature and precipitation are $12.0{ }^{\circ} \mathrm{C}$ and $330.8 \mathrm{~mm}$, respectively. Kurşun and Dengiz (2018) determined soil temperature and moisture rejime as mesic and weak aridic using Newhall simulation model (Newhall, 1972; Van Wambeke, 2000) (Figure 3).
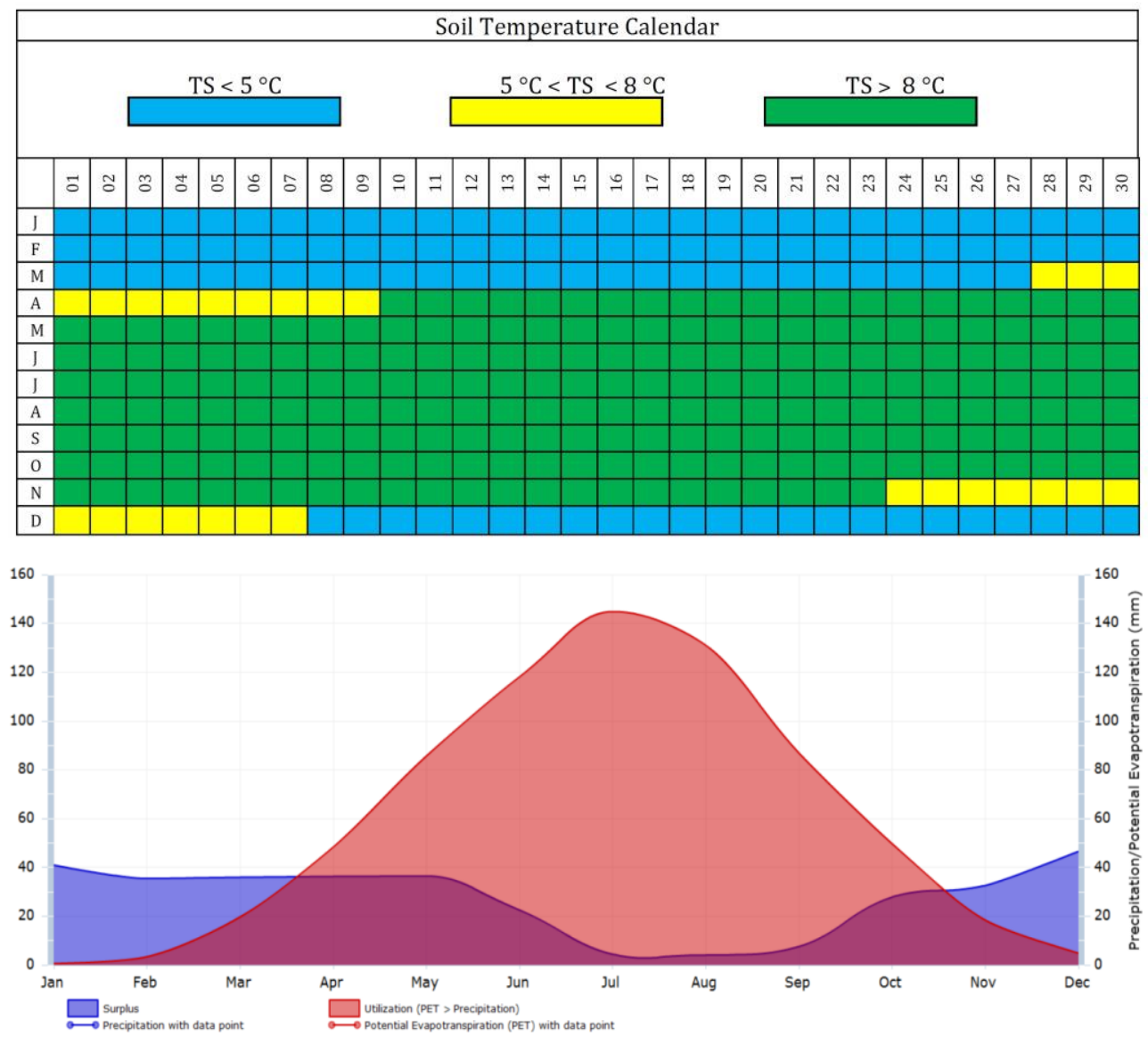

Figure 3. Soil moisture and temperature regime diagrams of the study area's soil

General geological pattern of the study area are marl, lime stone parent materials which are lacustrine origin and kolluvial and alluvial deposits (Murat ve Temur, 1995). According to CORINE-2012 land use land cover classification, the study area has been mostly used as dry farming and pasture lands. Moreover, barren and stoniness lands locate on southern and northern west parts of the study area (Figure 4). 


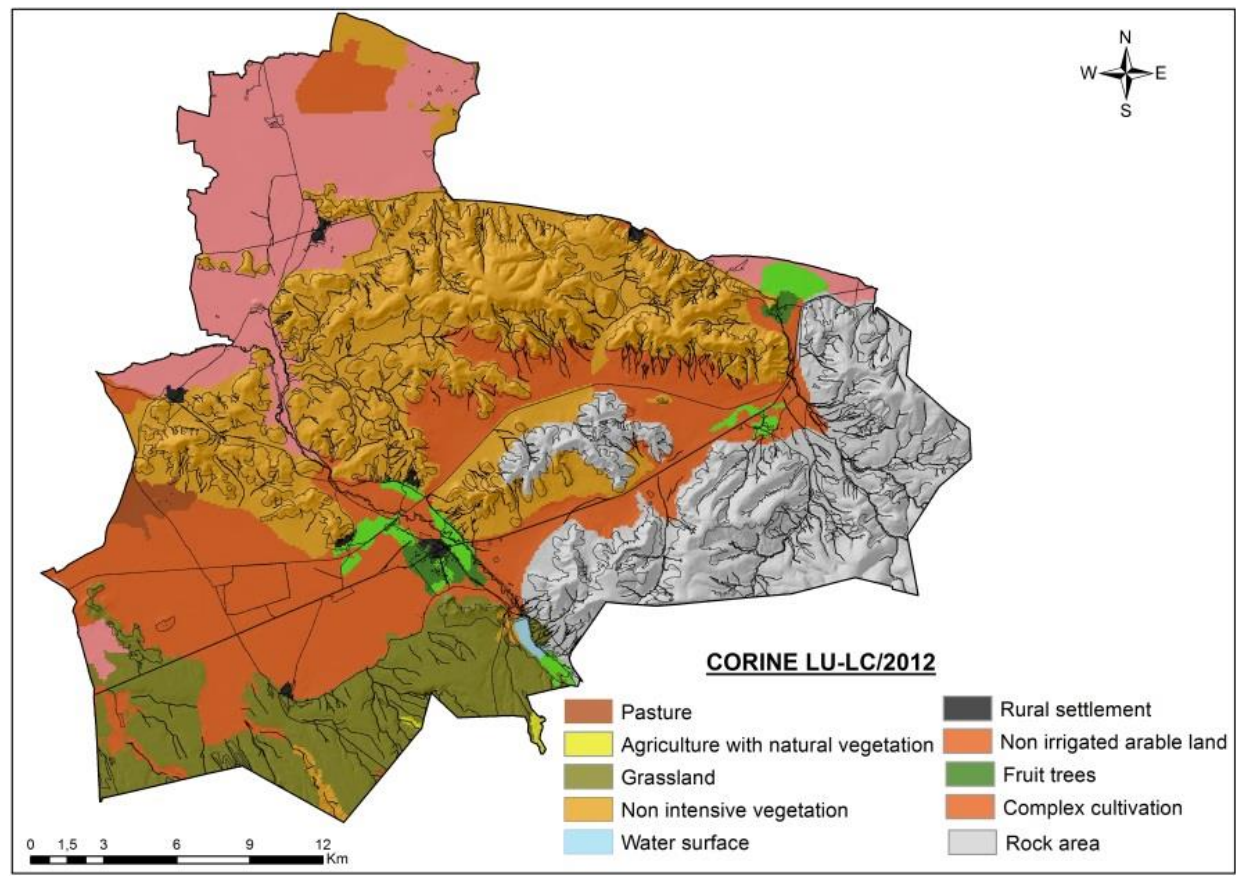

Figure 4. Land use and land cover map of the Study area

\section{Method}

Land suitability model based on the quantitative assessment of the agro-ecological evaluation in the study area for the land use types (LUTs) of rainfed agriculture, irrigated agriculture, range land, and nonagricultural area was developed by General Directory of Agricultural Reform in the light of the FAO (1976) and Senol (1994) principles. A digital soil database scaled 1:10.000 was prepared by Kurşun and Dengiz (2018) entering the diagnostic physical and chemical characteristics for each land mapping unit (LMUs). A total of 2951 LMUs were described from digital soil data base. In addition 151 different LUTs were distinguished and their land use requirements (LURs) were determined by using related information and available data. Land suitability (LS) is a function of a set of LURs determined for LUTs (LURs LUTS $_{\text {) }}$ and a set of land characteristics (LCs) measured for LMUs ( $\mathrm{LCs}_{\mathrm{LMU}}$ ) as follows:

$$
\mathrm{LS}_{\mathrm{LMUs}} \text { for LUTs }=\mathrm{f}\left\{\mathrm{LCS}_{\mathrm{LMUS}}, \mathrm{LURS}_{\mathrm{LUTS}}\right\}
$$

The land suitability index (LSI) of the LMUs for each LUT was calculated using the multiplicative combination of suitability rating index (SRI) as follows:

$$
\text { LSI LMUx_LUTy }_{2} \prod_{\mathrm{i}=1}^{\mathrm{n}} \text { SRILCix_LMUx_LUTy , }
$$

$\mathrm{LCi} \in[0 \ldots 1]$

Where; LSI values show the degree to which the requirements of the LUTs matched each LMU. LSI values were also expressed according to a rating scale of suitability classification for each LUT. At the same time, all LCs were standardized according to the common scale $[0 \ldots 1]$ where the least beneficial value of LC is 0 and the most beneficial value of LC is 1 . In other words, the limiting nature of each LC is taken into account by its effect in reducing productivity. During agronomic analysis, the higher SRI values represented the greater suitability of LMUs for each LUT, namely, the suitability of each identified LMU and LUT was assessed using the model to generate a Land Suitability Index (LSI) and suitability class for LUTs presented in Table 1.

Table 1. Land suitability index (LSI) and suitability class for LUTs

\begin{tabular}{lcl}
\hline LSI & Symbol & Suitability classes \\
\hline $1.00-0.90$ & $\mathrm{~S} 1$ & Highly suitable \\
$0.89-0.75$ & $\mathrm{~S} 2$ & Moderately suitable \\
$0.74-0.50$ & $\mathrm{~S} 3$ & Marginally suitable \\
$0.49-0.25$ & $\mathrm{~N} 2$ & Currently not suitable \\
$0.24-0.00$ & $\mathrm{~N} 2$ & Permanently not suitable \\
\hline
\end{tabular}

All of the LUTs were automatically distributed to land use groups using the model for each type of LMU to determine Potential Land Use Groups (PLUG). Furthermore, the input data of digital soil map databases were examined using model for suitability ratings for agricultural uses (Table 2) 
Table 2. Suitability class for agricultural use

\begin{tabular}{lll}
\hline Relative LMU index & Symbol & Classes \\
\hline $1.00-0.90$ & S1 & Best \\
$0.89-0.75$ & S2 & Relatively good \\
$0.74-0.50$ & S3 & Problematic \\
$0.49-0.20$ & N2 & Restricted \\
$0.19-0.00$ & N2 & Non-agriculture \\
\hline
\end{tabular}

In the final process of land evaluation, a suitability map for agricultural use was obtained. Thus, the results were added to the soil database for each LMU. The values were also used to generate a rain fed agriculture suitability map, an irrigated agriculture suitability map, non-agricultural use suitability map, a potential land use group's map, and suitability map for agricultural uses of the study area using GIS.

\section{Results and Discussion}

Land use groups which are horticulture groups (B), field groups (T), vegetable groups (S) were generated using the model for each type of LMU to determine Potential Land Use Groups (PLUG) which was given in Table 3, 4, 5 and Figure 5, 6 and 7. In this study, land evaluation is expected to be the prediction of land potential for productive LUTs, and generally the comparison or match of the requirements of each potential land use through the characteristics of each type of land. Therefore, it is essential to assess the cultivated area in order to select or determine the best land use types. All of LUTs were determined by taking into account the prevailing physical, ecological, economic, and social conditions of the region. Eighteen LUTs were determined in horticulture groups which are vineyard, poplar, almond, walnut, apple, plum, apricot, quince, berry, cherry, nectarine, peach, sour cherry, rose hip, blackberry, medlar and cranberry. Distribution of the horticulture suitability classes showed that $14.8 \%$ of the study area soils were not suitable for any type of horticulture agricultural applications (B0). About one-third of the study (33\%) area is suitable plum, apricot, vineyard, almond, walnut, apple, pear, poplar, quince and berry. Only $0.5 \%$ of the study area soils were suitable for all of the horticulture agriculture land use types (B17).

Table 3. Horticulture land use groups

\begin{tabular}{llr}
\hline Code & LUTs & ha \\
\hline B0 & not suitable for this classification & 70515,8 \\
B1 & vineyard, & 14,8 \\
B2 & vineyard, poplar & 4,9 \\
B3 & vineyard, almond, walnut, & 3124,0 \\
B4 & vineyard, almond, walnut, apple, & 37,1 \\
B5 & plum, apricot, vineyard, almond, walnut, apple, poplar, & 33297,2 \\
B6 & plum, apricot, vineyard, almond, walnut, apple, pear, poplar, & 7,0 \\
B7 & plum, Apricot, vineyard, almond, walnut, apple, Pear, poplar, Quince & 42413,1 \\
B8 & plum, Apricot, vineyard, almond, walnut, apple, Pear, poplar, quince, Berry, & 8,9 \\
B9 & plum, Apricot, vineyard, almond, walnut, apple, Pear, poplar, Quince, Berry, cherry & 31816,5 \\
B10 & plum, Apricot, vineyard, almond, walnut, apple, Pear, poplar, Quince, Berry, Nectarine, & 6,7 \\
B11 & plum, Peach, Apricot, vineyard, almond, walnut, apple, Pear, poplar, Quince, Berry, Cherry, & 1547,3 \\
B12 & plum, Peach, Apricot, vineyard, almond, walnut, apple, Pear, poplar, Quince, Berry, Nectarine & 0,3 \\
B13 & plum, Peach, apricot, vineyard, almond, walnut, apple, Pear, poplar, Quince, Cherry, Nectarine, & 2322,0 \\
& plum, Peach, Apricot, vineyard, almond, walnut, apple, Pear, poplar, Quince, Berry, Sour cherry, & 0,5 \\
B14 & Cherry, Nectarine, & 32,9 \\
& Erik, Apricot, vineyard, almond, walnut, apple, Pear, poplar, Quince, Berry, Sour cherry, Cherry, & 0,8 \\
B15 & Nectarine, Rose hip, Backberry, & 396765,2 \\
& plum, Peach, Apricot, vineyard, almond, walnut, apple, Pear, poplar, Quince, Berry, Sour cherry, & 3,4 \\
B16 & Cherry, Nectarine, Rose hip, Backberry, Cranberry & 0,1 \\
& plum, Peach, apricot, vineyard, almond, walnut, apple, Pear, poplar, Quince, Berry, Sour cherry, & 0,0 \\
B17 & Cherry, Nectarine, Rose hip, Backberry, Medlar, Cranberry, & 0,0 \\
\hline Total & & 0,0 \\
\hline
\end{tabular}

Twenty LUTs were determined in field crop groups which are rise, sugar beet, wheat, barley, vetch, sunflower, safflower, cole, anasone, hash, corn, avena, rey, tiritikale, alfalfa, trefoil, tare, linen, cannabis and sorghum. Distribution of the field crop suitability classes showed that $20.7 \%$ of the study area soils were not suitable for any type of field crop agricultural applications (T0). On the other hand about $34 \%$ of the study area is suitable for T17 including safflower, sunflower, cole, anasone, hash, sugar beet, corn, wheat, barley, avena, rey, alfalfa, tare, vetch and trefoil. 


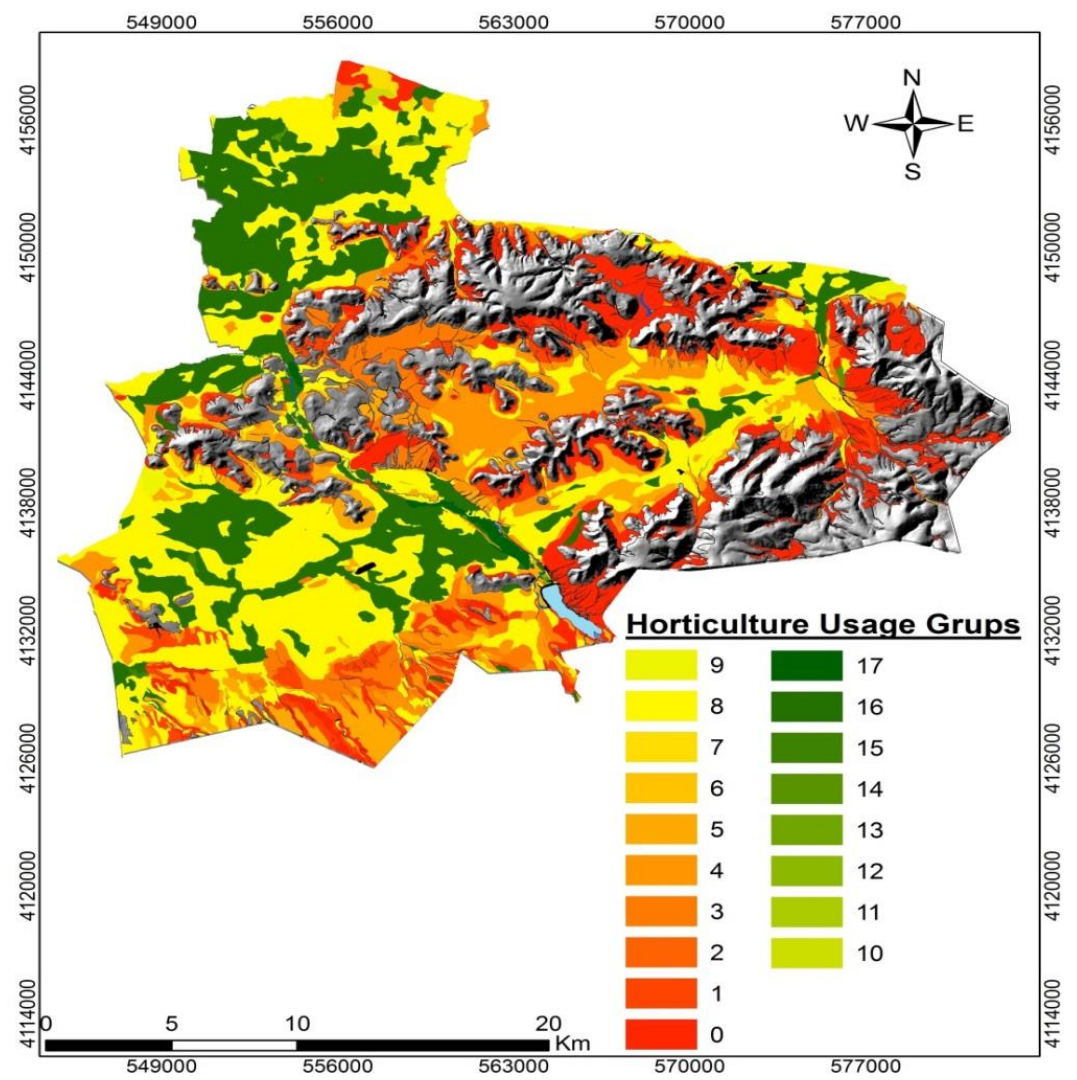

Figure 5. Distribution of the horticulture suitability class map of the study area Table 4. Field crop land use groups

\begin{tabular}{|c|c|c|c|}
\hline Code & LUTs & ha & $\%$ \\
\hline T0 & not suitable for this classification & 9859,1 & 20,7 \\
\hline $\mathrm{T} 1$ & Rice, & 9,1 & 0,0 \\
\hline $\mathrm{T} 2$ & Sugar beet, & 101,7 & 0,2 \\
\hline T3 & Wheat, Barley, & 3006,6 & 6,3 \\
\hline $\mathrm{T} 4$ & Wheat, Barley, Vetch, & 133,4 & 0,3 \\
\hline T5 & Sunflower, Suger beet, Wheat, Barley, & 13,2 & 0,0 \\
\hline T6 & Safflower, Cole, Wheat, Barley, Vetch, & 176,9 & 0,4 \\
\hline $\mathrm{T} 7$ & Cole, Anasone, Hash, Sugar beet, Wheat, Barley, Vetch, & 58,6 & 0,1 \\
\hline T8 & Cole, Anasone, Hash, Sugar beet, Corn, Wheat, Barley, Vetch, & 31,9 & 0,1 \\
\hline T9 & Sunflower, Cole, Anasone, Hash, Sugar beet, Corn, Wheat, Barley, Vetch, & 1851,5 & 3,9 \\
\hline T10 & Cole, Anasone, Hash, Wheat, Barley, Avena, Rey, Alfalfa, Trefoil, Vetch, & 9,5 & 0,0 \\
\hline T11 & Cole, Anasone, Hash, Rice, Wheat, Barley, Avena, Rey, Alfalfa, Vetch, & 3,4 & 0,0 \\
\hline T12 & $\begin{array}{l}\text { Safflower, Sunflower, Cole, Anasone, Hash, Sugar beet, Corn, Wheat, Barley, Vetch, } \\
\text { Safflower, Sunflower, Cole, Anasone, Hash, Sugar beet, Corn, Wheat, Barley, Avena, Rey, Alfalfa, }\end{array}$ & 3835,5 & 8,1 \\
\hline T13 & $\begin{array}{l}\text { Vetch, } \\
\text { Safflower, Sunflower, Cole, Anasone, Hash, Sugar beet, Corn, Wheat, Barley, Avena, Rey, Alfalfa, }\end{array}$ & 1908,9 & 4,0 \\
\hline T14 & $\begin{array}{l}\text { Tare, Vetch, } \\
\text { Safflower, Sunflower, Cole, Anasone, Hash, Suger beet, Corn,Wheat, Barley, Avena, Rey, Alfalfa, }\end{array}$ & 81,9 & 0,2 \\
\hline T15 & $\begin{array}{l}\text { Vetch, Trefoil, } \\
\text { Safflower, Cole, Anasone, Hash, Suger beet, Corn, Rice, Wheat, Barley, Avena, Rey, Alfalfa, Tare, }\end{array}$ & 96,2 & 0,2 \\
\hline T16 & $\begin{array}{l}\text { Trefoil, Vetch, } \\
\text { Safflower, Sunflower, Cole, Anasone, Hash, Sugar beet, Corn,Wheat, Barley, Avena, Rey, Alfalfa, Tare, }\end{array}$ & 0,1 & 0,0 \\
\hline T17 & $\begin{array}{l}\text { Vetch, Trefoil, } \\
\text { Safflower, Sunflower, Cole, Anasone, Hash, Sugar beet, Corn, Rice, Wheat, Barley, Avena, Rey, Alfalfa, }\end{array}$ & 15987,6 & 33,6 \\
\hline T18 & $\begin{array}{l}\text { Tare, Trefoil, Vetch, } \\
\text { Safflower, Sunflower, Cole, Anasone, Hash, Sugar beet, Corn, Wheat, Barley, Avena, Rey, Alfalfa, }\end{array}$ & 22,4 & 0,0 \\
\hline T19 & $\begin{array}{l}\text { Tare, Vetch, Trefoil, Sorghum } \\
\text { Safflower, Sunflower, Cole, Anasone, Hash, Sugar beet, Corn, Rice, Linen, Cannabis, Wheat, Barley, }\end{array}$ & 10127,8 & 21,3 \\
\hline $\mathrm{T} 20$ & $\begin{array}{l}\text { Avena, Rey, Alfalfa,Tare, Trefoil, Vetch, } \\
\text { Safflower, Sunflower, Cole, Anasone, Hash, Sugar beet, Corn, Rice, Linen, Cannabis, Wheat, Barley, }\end{array}$ & 19,7 & 0,0 \\
\hline $\mathrm{T} 21$ & $\begin{array}{l}\text { Avena, Rey, Alfalfa, Tare, Trefoil, Vetch, Trefoil, } \\
\text { Safflower, Sunflower, Cole, Anasone, Hash, Sugar beet, Corn, Rice, Linen, Cannabis, Wheat, Barley, }\end{array}$ & 148,7 & 0,3 \\
\hline $\mathrm{T} 22$ & Avena, Rey, Alfalfa, Tare, Trefoil, Vetch, Trefoil, Sorghum, & 117,4 & 0,2 \\
\hline Total & & 47600,9 & 100,0 \\
\hline
\end{tabular}




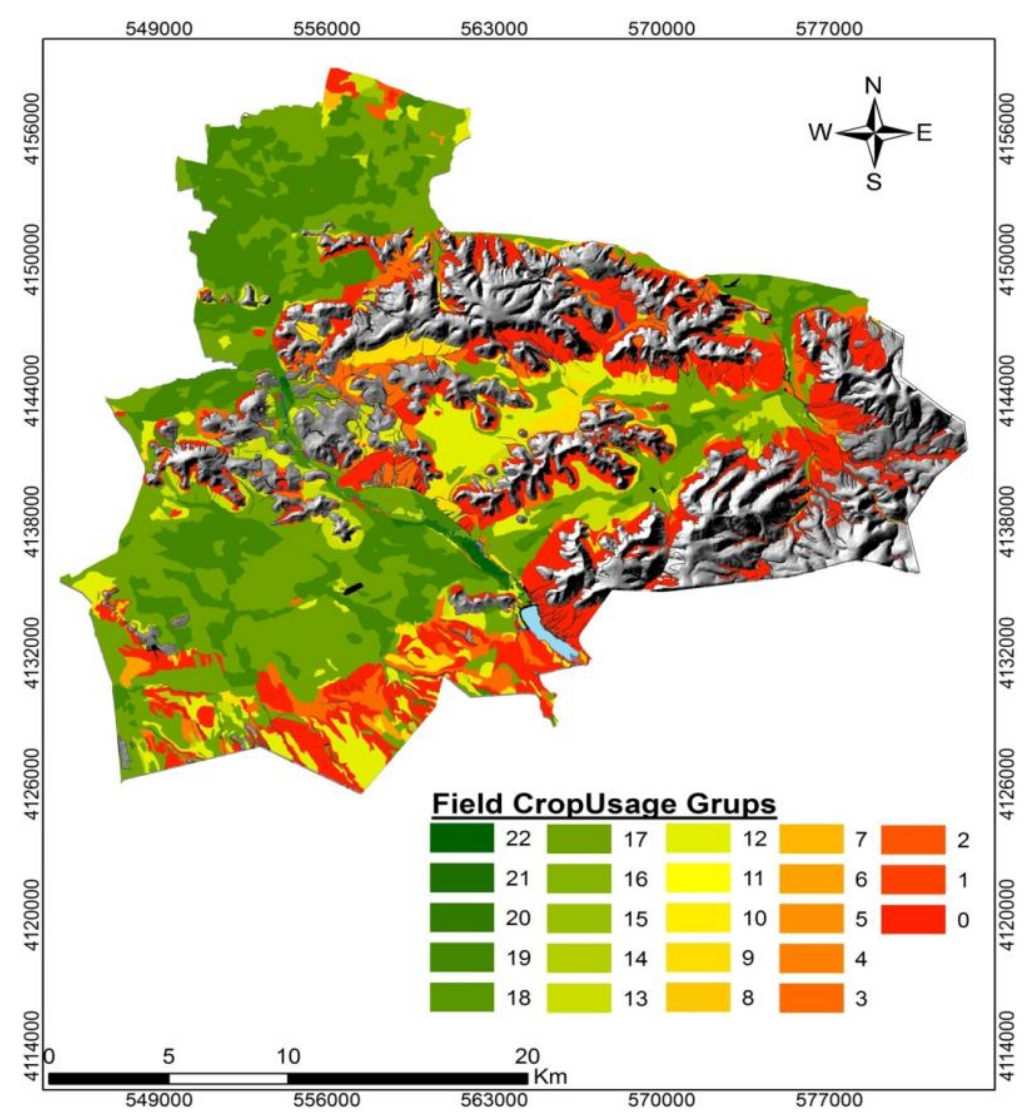

Figure 6. Distribution of the field crop suitability class map of the study area

Thirty-two LUTs were determined in field crop groups which are tomato, melon, water melon, onion, eggplant, pepper, cucumber, bean, reddish shell bean, strawberry, cabbage, gherkin, potato, garlic, lettuce, broad bean, okra, leek, cauli, spinach, parsley, radish, carrot, sunroot, mint, pepperwort, thyme, pea, kind of watercress, rutabaga and broccoli. Distribution of the field crop suitability classes showed that $35.4 \%$ of the study area soils were not suitable for any type of field crop agricultural applications (S0). Only $0.5 \%$ of the study area soils were suitable for almost all of the vegetable crop agriculture land use types (S24).

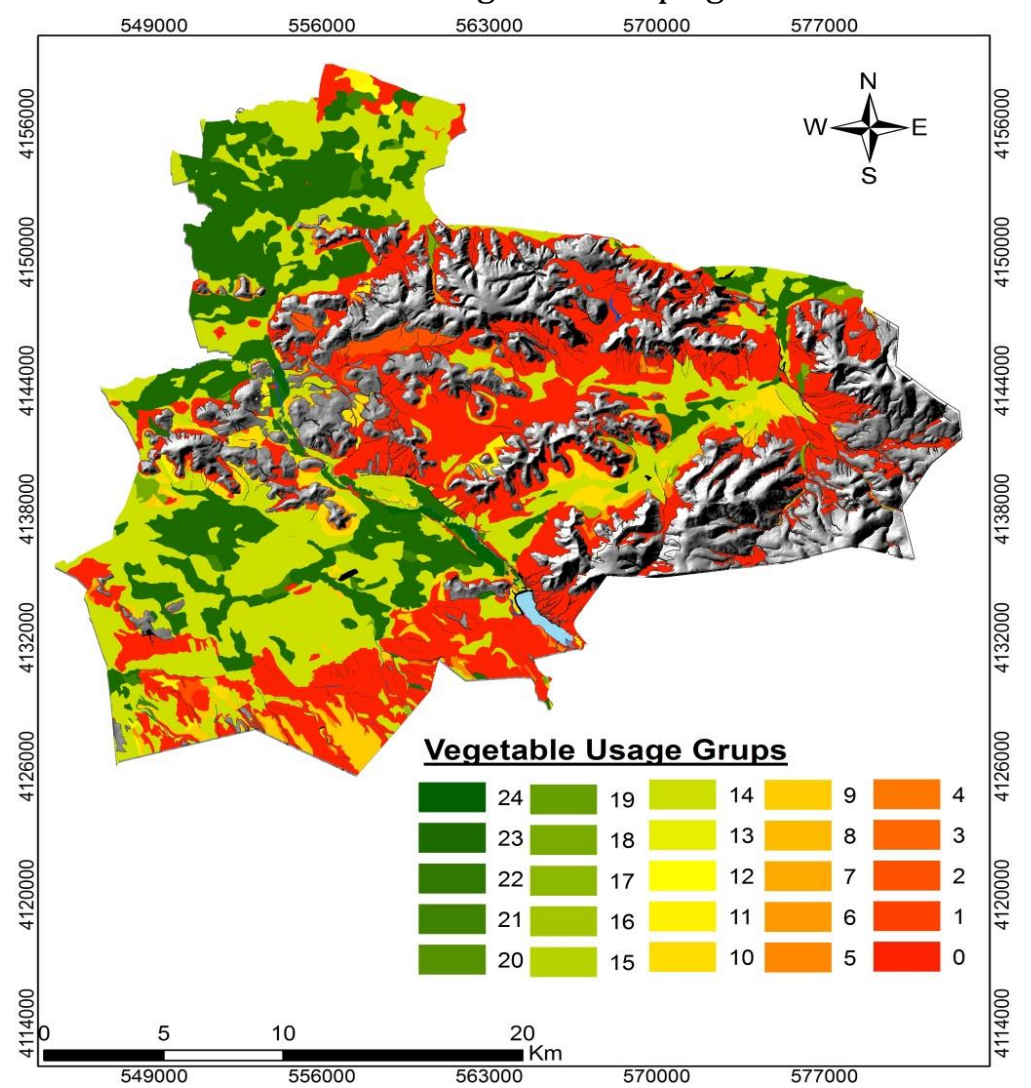

Figure 7. Distribution of the vegetable crop suitability class map of the study area 
Table 5. Vegetable crop land use groups

\begin{tabular}{|c|c|c|c|}
\hline Code & LUTs & ha & $\%$ \\
\hline S0 & Not suitable for this classification & 16831,3 & 35,4 \\
\hline S1 & Tomato, & 1,16 & 0,0 \\
\hline S2 & Melon, Water melon, & 592,98 & 1,2 \\
\hline S3 & Tomato, Onion, & 13,17 & 0,0 \\
\hline S4 & Melon, Water melon, Tomato, Eggplant, Pepper, & 30,88 & 0,1 \\
\hline S5 & $\begin{array}{l}\text { Melon, Water melon, Tomato, Eggplant, Pepper, Onion, Cucumber, Bean, Reddish shell bean, } \\
\text { Strawberry, Melon, Tomato, Eggplant, Pepper, Cucumber, Gherkin, Bean, Reddish shell bean, }\end{array}$ & 453,37 & 1,0 \\
\hline S6 & $\begin{array}{l}\text { Potato, } \\
\text { Strawberry, Melon, Water melon, Tomato, Eggplant, Pepper, Onion, Garlic, Cucumber, Bean, }\end{array}$ & 0,29 & 0,0 \\
\hline S7 & $\begin{array}{l}\text { Reddish shell bean, } \\
\text { Melon, Water melon, Cabbage, Tomato, Eggplant, Pepper, Onion, Cucumber, Lettuce, Potato, }\end{array}$ & 193,30 & 0,4 \\
\hline S8 & $\begin{array}{l}\text { Broad bean, } \\
\text { Strawberry, Melon, Water melon, Tomato, Eggplant, Pepper, Onion, Garlic, Cucumber, Bean, }\end{array}$ & 3,71 & 0,0 \\
\hline S9 & $\begin{array}{l}\text { Reddish shell bean, Potato, } \\
\text { Strawberry, Melon, Water melon, Tomato, Eggplant, Pepper, Onion, Garlic, Cucumber, }\end{array}$ & 970,01 & 2,0 \\
\hline S10 & $\begin{array}{l}\text { Gherkin, Bean, Reddish shell bean, Potato, } \\
\text { Strawberry, Melon, Water melon, Tomato, Eggplant, Pepper, Onion, Garlic, Cucumber, }\end{array}$ & 1492,40 & 3,1 \\
\hline S11 & $\begin{array}{l}\text { Gherkin, Okra, Bean, Reddish shell bean, Potato, } \\
\text { Strawberry, Melon, Water melon, Tomato, Eggplant, Pepper, Onion, Garlic, Cabbage, }\end{array}$ & 392,95 & 0,8 \\
\hline S12 & $\begin{array}{l}\text { Cucumber, Gherkin, Okra, Leek, Lettuce, Bean, Reddish shell bean, Cauli, Potato, } \\
\text { Strawberry, Melon, Water melon, Cabbage, Tomato, Eggplant, Pepper, Onion, Garlic, Cabbage, }\end{array}$ & 47,59 & 0,1 \\
\hline S13 & $\begin{array}{l}\text { Cucumber, Gherkin, Okra, Leek, Lettuce, Bean, Reddish shell bean, Cauli, Potato, } \\
\text { Strawberry, Melon, Water melon, Tomato, Eggplant, Pepper, Onion, Garlic, Cabbage, } \\
\text { Cucumber, Gherkin, Okra, Spinach, Leek, Lettuce, Bean, Parsley, Reddish shell bean, Cauli, }\end{array}$ & 7,87 & 0,0 \\
\hline S14 & $\begin{array}{l}\text { Potato, } \\
\text { Strawberry, Melon, Water melon, Tomato, Eggplant, Pepper, Onion, Garlic, Cabbage, } \\
\text { Cucumber, Gherkin, Okra, Spinach, Leek, Radish, Lettuce, Bean, Parsley, Reddish shell bean, }\end{array}$ & 15176,4 & 31,9 \\
\hline S15 & $\begin{array}{l}\text { Cauli, Potato, } \\
\text { Strawberry, Melon, Water melon, Cabbage, Tomato, Eggplant, Pepper, Onion, Garlic, Cabbage, } \\
\text { Cucumber, Gherkin, Okra, Spinach, Leek, Lettuce, Bean, Parsley, Reddish shell bean, Cauli, }\end{array}$ & 9,17 & 0,0 \\
\hline S16 & $\begin{array}{l}\text { Potato, } \\
\text { Strawberry, Melon, Water melon, Cabbage, Tomato, Eggplant, Pepper, Onion, Garlic, Cabbage, } \\
\text { Cucumber, Gherkin, Okra, Spinach, Leek, Radish, Lettuce, Bean, Parsley, Reddish shell bean, }\end{array}$ & 97,71 & 0,2 \\
\hline S17 & $\begin{array}{l}\text { Cauli, Potato, } \\
\text { Strawberry, Melon, Water melon, Cabbage, Tomato, Eggplant, Pepper, Onion, Garlic, Cabbage, } \\
\text { Cucumber, Gherkin, Okra, Spinach, Carrot, Leek, Lettuce, Bean, Parsley, Reddish shell bean, }\end{array}$ & 4,74 & 0,0 \\
\hline S18 & $\begin{array}{l}\text { Cauli, Potato, } \\
\text { Strawberry, Melon, Water melon, Cabbage, Tomato, Eggplant, Pepper, Onion, Garlic, Cabbage, } \\
\text { Cucumber, Gherkin, Okra, Spinach, Carrot, Leek, Radish, Lettuce, Bean, Parsley, Reddish shell }\end{array}$ & 366,66 & 0,8 \\
\hline S19 & $\begin{array}{l}\text { bean, Cauli, Potato, } \\
\text { Strawberry, Melon, Water melon, Cabbage, Tomato, Eggplant, Pepper, Onion, Garlic, Cabbage, } \\
\text { Cucumber, Gherkin, Okra, Spinach, Carrot, Leek, Radish, Lettuce, Bean, Parsley, Reddish shell }\end{array}$ & 0,81 & 0,0 \\
\hline S20 & $\begin{array}{l}\text { bean, Cauli, Potato, } \\
\text { Strawberry, Melon, Water melon, Cabbage, Tomato, Eggplant, Pepper, Onion, Garlic, Cabbage, } \\
\text { Cucumber, Gherkin, Okra, Spinach, Carrot, Leek, Radish, Lettuce, Bean, Parsley, Reddish shell }\end{array}$ & 33,12 & 0,1 \\
\hline S21 & $\begin{array}{l}\text { bean, Cauli, Potato, Broad bean, } \\
\text { Strawberry, Melon, Water melon, Cabbage, Tomato, Eggplant, Pepper, Onion, Garlic, Cabbage, } \\
\text { Cucumber, Gherkin, Okra, Spinach, Carrot, Leek, Radish, Lettuce, Bean, Parsley, Reddish shell }\end{array}$ & 478,66 & 1,0 \\
\hline S22 & $\begin{array}{l}\text { bean, Cauli, Potato, Sunroot, Broad bean, Mint, Thyme, Kind of watercress, } \\
\text { Strawberry, Melon, Water melon, Cabbage, Tomato, Eggplant, Pepper, Onion, Garlic, Cabbage, } \\
\text { Cucumber, Gherkin, Okra, Spinach, Carrot, Leek, Radish, Lettuce, Bean, Parsley, Reddish shell }\end{array}$ & 6,67 & 0,0 \\
\hline S23 & $\begin{array}{l}\text { bean, Cauli, Potato, Sunroot, Broad bean, Mint, Thyme, Kind of watercress, Pepperwort, } \\
\text { Strawberry, Melon, Water melon, Cabbage, Tomato, Eggplant, Pepper, Onion, Garlic, Cabbage, } \\
\text { Cucumber, Gherkin, Okra, Spinach, Carrot, Leek, Radish, Lettuce, Bean, Parsley, Reddish shell } \\
\text { bean, Cauli, Broccoli, Potato, Sunroot, Broad bean, Rutabaga, Mint, Thyme, Pea, Kind of }\end{array}$ & 10136,46 & 21,3 \\
\hline S24 & watercress, Pepperwort, & 259,45 & 0,5 \\
\hline Total & & 47600,9 & 100,0 \\
\hline
\end{tabular}

The distribution of land suitability for agricultural uses showed that $72.7 \%$ of the study area soils were classified as best (S1) and relatively good (S2). The distribution of the problematic (S3) and restricted (C4) lands was $12.5 \%$ and $6.4 \%$ (Figure 8 ). Finally, only $8.4 \%$ of the study area soils were not suitable for agricultural uses (Table 6). 
Table 6. Suitability classes for agricultural use

\begin{tabular}{|c|c|c|c|}
\hline Description & Class & ha & $\%$ \\
\hline Best & S1: 1-5 & 27243,9 & 57,2 \\
\hline Relatively good & S2: 6 & 7379,0 & 15,5 \\
\hline Problematic & S3: 7 & 5944,1 & 12,5 \\
\hline Restricted & $\mathrm{N} 1: 8$ & 3050,7 & 6,4 \\
\hline Non-agriculture & N2: $9-10$ & 3983,1 & 8,4 \\
\hline Total & & 47600,9 & 100,0 \\
\hline
\end{tabular}

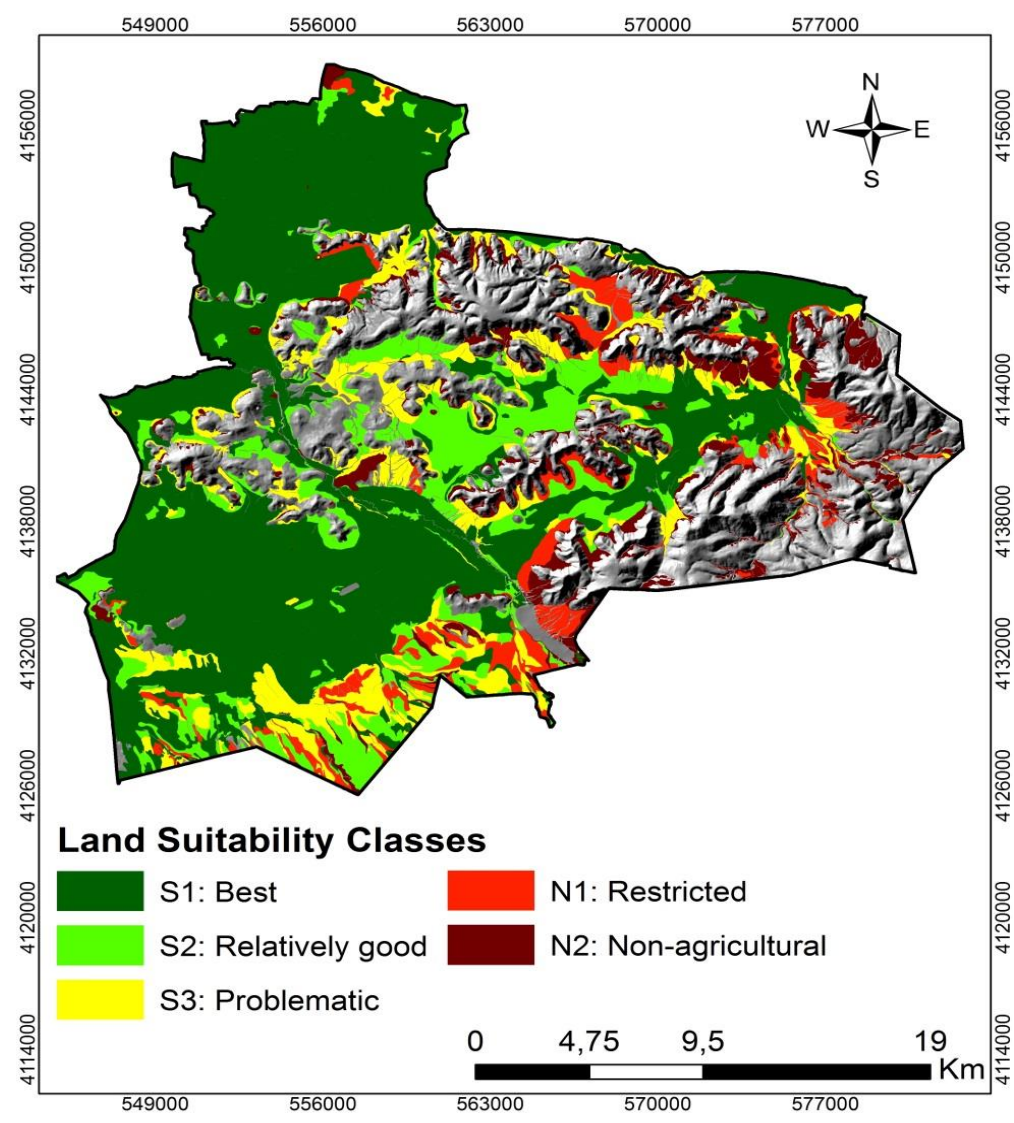

Figure 8. Suitability classes for agricultural use map of the study area

\section{Conclusion}

This current study was performed in Ayancık district of Karaman province located in arid and semiarid environmental ecosystem in order to present an example of alternative agricultural use by considering environmental conditions, because all land can be used for almost all purposes if sufficient inputs are supplied. Each land unit has its own potentialities and limitations, and each land use has its own biophysical requirements. It was found that $8.4 \%$ of the study area was not suitable for agricultural activities. In addition, this study confirms the capability of GIS to integrate spatial and attribute data and to offer a quick and reliable method of land suitability assessment with high accuracy. On the other hand, while GIS has been a powerful tool to handle spatial data in land-use analysis, application of this tool alone could not overcome the issue of inconsistency in expert opinion when trying to judge and assign relative importance to each of many criteria considered in a suitability analysis. In conclusion, this research gives suggestions for some alternative applications for the use of land and soil resources and the improvement of agriculture by taking into account the importance of natural values.

\section{References}

Anderson, L.T., 1987. Seven methods for calculating land capability/suitability. Planning Advisory Service (PAS), Report No.402, American Planning Association, Chicago, USA. 20p.

Bagherzadeh, A., Mansouri, M.R., 2011. Physical land suitability evaluation for specific cereal crops using GIS at Mashhad Plain, northeast of Iran. Frontiers of Agriculture in China 5 (4): 504-513.

Dengiz, O., 2002. Ankara-Gölbaşı İlçesi ve Yakın Çevresinde Yayılım gösteren arazilerin kalite durumlarının belirlenmesinde parametrik metot yaklaşımı. Selçuk Üniversitesi Ziraat Fakültesi Tarım Bilimleri Dergisi 16(30): 59-69 [in Turkish]. 
Dengiz, O., Bayramin, İ., Yüksel, M., 2003. Geographic information system and remote sensing based land evaluation of Beypazarı area soils by ILSEN model. Turkish Journal of Agriculture and Forestry 27(3): 145-153.

Dengiz, O., İ. Bayramin, Usul, M., 2005. Kahramanmaraş tarım işletmesi topraklarının kalite durumlarının belirlenmesi. Ankara Üniversitesi Ziraat Fakültesi Tarım Bilimleri Dergisi 11(1): 45-50 [in Turkish].

Dengiz, O., Ozcan, H., Köksal, E.S., Baskan, O., Kosker, Y., 2010. Sustainable natural resource management and environmental assessment in the Salt Lake (Tuz Golu) Specially Protected Area. Environmental Monitoring and Assessment 161(1-4): 327-342.

Dengiz, 0., 2013. Land suitability assessment for rice cultivation based on GIS modeling. Turkish Journal of Agriculture and Forestry. 37(3): 326-334.

Dengiz, O., Sarığlu, F.E., 2013. Arazi değerlendirme çalışmalarında parametrik bir yaklaşım olan doğrusal kombinasyon tekniği. Tarım Bilimleri Dergisi 19 (2): 101-112 [in Turkish].

FA0, 1976. A framework for land evaluation. Food and Agriculture Organization of The United Nations. Soils Bulletin No. 32, Rome, Italy. Available at [Access date: 01.04.2019]: http://www.fao.org/docrep/x5310e/x5310e00.htm

FAO, 2014. Building a common vision for sustainable food and agriculture, principles and approaches. Rome, Italy. Available at [Access date: 01.04.2019]: http://www.fao.org/3/a-i3940e.pdf

Flynn, K.C., 2016. An exploration of agricultural lands devoted to corn-based ethanol production. Papers in Applied Geography 2(3): 315-325.

Hamerlinck, J.D., S.N. Lieske., 2015. Siting carbon conversion energy facilities with spatial multicriteria decision analysis. Papers in Applied Geography 1 (2):197-204.

Laingen, C., 2015. A spatiotemporal analysis of sorghum in the United States. Papers in Applied Geography 1(4): 307311.

Girma, R., Moges, A., Quraishi, S., 2015. GIS based physical land suitability evaluation for crop production in Eastern Ethiopia: A case study in Jello Watershed. Agrotechnology 5(1): 2-7.

Hopkins, L.D., 1977. Methods of generating land suitability maps: A comparative evaluation. Journal of American Institute of Planners 43(4): 386-400.

Khiddir, S.M., 1986. A statistical approach in the use of parametric systems applied to the FAO framework for land evaluation. PhD thesis, Ghent State University, Ghent, Belgium.

Jafarzadeh, A., Alamdari, A.P., Neyshabouri, M.R., Saedi, S., 2008. Land suitability evaluation of Bilverdy Research Station for wheat, barley, alfalfa, maize and sunflower. Soil and Water Research 3:S81-S88.

Karimi, F., Sultana, S., Babakan, A., Royall, D., 2018. Land suitability evaluation for organic agriculture of wheat using GIS and multicriteria analysis. Papers in Applied Geography 4(3): 326-342.

Kurşun, G., Dengiz, O. 2018. Arid Karasal ekosistem koşulları altında oluşmuş toprakların sınıflaması ve dağılımlarının belirlenmesi. Toprak Su Dergisi 7(2): 1-10 [in Turkish].

Mendas, A., Delali, A., 2012. Integration of MultiCriteria Decision Analysis in GIS to develop land suitability for agriculture: Application to durum wheat cultivation in the region of Mleta in Algeria. Computers and Electronics in Agriculture 83: 117-126.

Mustafa, A.A., Singh, M., Sahoo, R.N., Ahmed, N., Khanna, M., Sarangi, A., Mishra, A.K., 2011. Land suitability analysis for different crops: A multi criteria decision making approach using remote sensing and GIS. Researcher 3(12): 6184.

Murat, A., Temur, S., 1995. Karaman (Ayrancı-Karaman) yöresi talk yatakları. Maden Tetkik ve Arama Genel Müdürlüğü, Orta Anadolu II. Bölge Müdürlüğü. Konya-Selçuk Üniversitesi, Jeoloji Mühendisliği Bölümü, Konya Türkiye Jeoloji Bülteni 38(1): 95-102.

Newhall, F., 1972. Calculation of soil moisture regimes from the climatic record, Revision 4. USDA Soil conservation service, Washington D.C., USA.

Rabia, H.A, Terribile, F., 2013. Introducing a new parametric concept for land suitability assessment. International Journal of Environmental Science and Development 4(1): 15-19.

Senol, S., 1994. Bilgisayar destekli bir model yardımıyla Göksu deltası topraklarının tarımsal kullanımına uygunluk siniflaması. Turkish Journal of Agriculture and Forestry 18(5): 437- 443 [in Turkish].

Sys, C., Van Ranst, E., Debaveye, J., 1991. Land evaluation. Part I Principles in land evaluation and crop production calculations. General administration for development cooperation (GADC), Agricultural Publications No.7, Brussels, Belgium. pp.40-80.

Vargahan, B., Shahbazi, F., Hajrasouli, M., 2011. Quantitative and qualitative land suitability evaluation for maize cultivation in ghobadlou region, Iran. Ozean Journal of Applied Sciences 4(1): 91-104.

van Wambeke, A.R., 2000. The Newhall simulation model for estimating soil moisture and temperature regimes. Department of Crop and Soil Sciences. Cornell University, Ithaca, NY, USA. 